\title{
The Leadership Characteristics And Efficiency Of Local Administrative Organizations: A Case Study Of Local Administrative Organizations In The Lower North Region Of Thailand \\ Sombut Boonleaing, Valaya Alongkorn Rajabhat University, Thailand \\ Saman Ngamsanit, Valaya Alongkorn Rajabhat University, Thailand \\ Saard Bunjetrit, Valaya Alongkorn Rajabhat University, Thailand Khak Muldet, Phetchabun Rajabhat University, Thailand \\ Patarapong Kroeksakul, Prince of Songkla University, Thailand \\ Thongphon Promsaka Na Sakolnakorn, Prince of Songkla University, Thailand
}

\begin{abstract}
The objective of this study was to examine the leadership and the efficiency of the chief executive of local government organizations. We asked chief executives of local government organizations in nine provinces in the lower northern region of Thailand to fill out questionnaires and participate in in-depth interviews. Then we used a computer program (SPSS) to do a quantitative analysis of the data, and we also did a content analysis using a qualitative method. The results of this study found that the characteristics of local government leaders are vision, education and knowledge, good personality, high morality, attention to work, responsibility, and participation.
\end{abstract}

Keywords: Leadership; Local Administrative Organization; Efficiency

\section{INTRODUCTION}

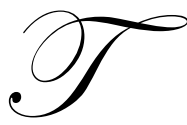

oday's leaders act in a global, complex, uncertain and interconnected business environment. They are challenged by the need to reduce complexity and uncertainty for people and provide a desirable picture of the future for the people they lead. Their success depends on the ability of a firm and its leadership to act responsibly with respect to all stakeholders in the business, organization, society and the environment (Crossan, Vera and Nanjad, 2008).

Local government officials in Thailand are usually the people who are powerful. Small political groups attempt to use their power to benefit a group illegitimately. People do not trust the local administration because it is a closed system and has an opaque system of management. Ordinary people cannot participate in the administration (The Department of Local Administration, 2006: 48).

If they can be the chief executive of local government organizations, they will learn from their political experiences and develop their administrative skills. In addition, they will create relationships with people in society and control management to achieve goals they set to respond to the requirements of the people based on the principles of administrative decentralization (Set Khajon, 2003: 27).

Consequently, the person who takes the leadership position in local government will have an impact on whether administrative goals are met; i.e., services facilitation and building a sound infrastructure for people and society, such as providing adequate and clean water, roads, and electricity. However, in order for successful 
development to take place, the leader needs the cooperation of every person in his community. The difference between a successful and an unsuccessful organization is dependent on whether the administrator distributes responsibility to officers under his control and uses his leadership appropriately in the many situations that arise. Those who use their skills and efficiency to benefit the local administrative organization and their society will be successful (Hongtongkam, 1997: 15).

Therefore, the leader in the local government organization has an important role to direct work in the local administration, both directly and indirectly; for example, development of the local political administrative system. These are important factors that affect the administration and its development to effectively achieve its goals (Prasertsri, 2001: 24)

As mentioned above, it is important to study the leadership characteristics of the chief executive of the local administration to find out what creates strong leadership with the political power to develop a community.

\section{RESEARCH OBJECTIVE}

The aim was to study the responsibilities and leadership characteristics of the chief executive of local administrations.

\section{RESEARCH SCOPE}

We studied the chief executives of local administrations in the provinces in the lower northern section of Thailand - Phitsanulok, Uttaradit, Sukhothai, Tak, Kampangpetch, Nakhonsawan, Pichit, and Uthai Thani.

\section{RESEARCH METHODOLOGY}

This study employed both quantitative and qualitative methods. Using the quantitative method, we provided 400 questionnaires to chief executives of local administrations, including provincial administrative organizations, municipal organizations, and sub-district administrative organizations, and then analyzed the resulting data by using a computer program (SPSS) to derive statistics.

Using the qualitative methodology, we did an in-depth interview with 40 chief executives of provincial local organizations, including administrative organizations, municipal organizations, and sub-district administrative organization, and used content analysis to examine this data.

\section{RESULTS OF THE STUDY}

The study determined that most administrators are male between the ages of 41 and 50 . All of them had an undergraduate-level education and all of them were married and earned between 50,000 and 100,000 THB per month. They have worked as a chief executive of a local organization for 1 to 4 years and they have never been members of any groups and have not participated in general training programs.

The quantitative analysis of in-depth interviews with 40 chief executives of local organization administrators showed that in order to become a leader, a person must have knowledge, vision, and personality. A leader must have followers who support their work and they must understand their workers' ideas. A leader must not use power, money, position, or privileges to control his employees. However, leaders must use their responsibility and their authority to support their staff members.

The responsibilities of a chief executive of a local organization are:

1. To wield influence, the ideal leader must talk with workers about values, beliefs, and working standards. A leader should pay attention to the work. Leaders should be confident and show the power, ideals, beliefs, and values to which they adhere. 
2. A leader should use tools to motivate employees and pay attention to what is important to workers. After that, the leader should create additional tools to motivate workers to perform their best. Moreover, a leader should respond to the requirements of workers, support them, and give rewards when they perform their work well. Leaders should seek opportunities to praise their workers for quality work, while clearly defining responsibilities.

3. A leader should follow up on workers' ideas and support their creative activities. A leader must analyze and follow up on issues pertaining to his/her workers and, together with them, find solutions. A leader should listen to a worker's problems and help him/her solve it; and a leader should give advice to workers and encourage them to define problems in various ways. In addition, leaders must have weekly meetings with workers in all departments and give them the opportunity to discuss work-related issues and to solve them. Additionally, Elenkov and Manev (2005) found that the socio-cultural context of the organization is moderated by the relationship between a leader's behavior, the workers under his/her direction, and organizational innovation.

4. A leader should negotiate with workers about rewards for the successful completion of work. A leader should consider the effects of morality when making decisions. He should confidently and strictly enforce the organizational regulations to prevent mistakes. Leaders should support and promote workers to improve their strong points.

5. A leader should have a plan covering all aspects of organizational development, such as human resource development, job planning, and project management, and he should cut unnecessary processes. In addition, he should figure out how the work process can be done faster to meet deadlines. He should also review a project budget carefully.

Characteristics of a chief executive of a local organization are:

1. Vision - A leader has to know his role in the administration and have a clear plan that can apply to work processes. Moreover, a leader should have a vision and create a policy for local development.

2. Education and knowledge - A leader must have knowledge and continue learning to become a better manager of an organization. Peter M. Senge (1990) explained that better management comes from knowledge that includes: 1) personal mastery, 2) a mental model, 3) shared vision, 4) systemic thinking, and 5) a portfolio.

3. Personality - A leader should have a good personality, look clean, act nice, have good health, be reasonable, show confidence, and be smart in solving problems. In addition, a leader must demonstrate good communication skills.

4. Morality - A leader's behavior should be based on good morality.

5. Attention to work - A leader should think about the public benefit rather than his own. He should have a well thought out plan for the operation, good communication, and an efficient process to achieve the work.

6. Responsibility - A leader is a person that others can trust. He is confident, creative, experienced in work, and understands official regulations. He is a person who consistently expects good work.

7. Participation - A leader should participate in activities with others and spend time performing social work. He must trust his workers under his direction and provide them with opportunities to participate in solving problems. In addition, he needs to be adaptable and displays emotional equilibrium in all situations. Valaisathien, et al. (2000: 139) explained that leaders must participate in any process of the operation and provide people with opportunities to share ideas and work together to make decisions.

\section{CONCLUSION}

This study gives a view of the responsibilities and characteristics of leadership of a chief executive in local organization administration. It is important to know what the activities are and what they aim to do for the support of the organization, government officers and society. In addition, Bedian and Hunt (2006) suggest that the leader is mean to someone who is serving.

Finally, researchers hope that this study will benefit people who want to become leaders, and offer a view of how to manage people, what to do in order to support their organization and society, and how to provide satisfaction to the people under their control. For future study, one should study another region of Thailand to confirm and learn about differences from this study. 


\section{ACKNOWLEDGEMENT}

We would like to thank Phetchabun Rajabhat University for financial support and Dr. Boonthan Dokthaisong who helped us and recommended this research topic.

\section{AUTHOR INFORMATION}

Dr.Sombut Boonleaing is a Dean of Faculty of Humanities and Social Science at Phetchabun Rajabhat University, Thailand. He received his Doctorate degree in public administration from Valaya Alongkorn Rajabhat University, Thailand. He is a specialist in the management of public organizations, human resource management, etc.

Dr. Saman Ngamsanit is an associate professor who received his Ph.D. in Development Administration from National Institute of Development Administration. (NIDA) Thailand. He is a specialist in human resource management.

Dr. Saard Bunjetrit is a lecturer who received a DBA from The University of South Australia. He specializes in economics policy.

Dr. Khak Muldet is a lecturer who received a Ph.D. from Naresuan University, Thailand. He is a specialist in research methodology.

Dr. Patarapong Kroeksakul is a lecturer at faculty of natural resources, Prince of Songkla University Thailand. He received his Ph.D. from Khon Kaen University, Thailand. He is a specialist in socio-economic and agriculture system.

Dr. Thongphon Promsaka Na Sakolnakorn is a lecturer of the Faculty of Liberal Arts at the Prince of Songkla University, Thailand. He received his first Ph.D. in development science from Khon Kaen University, Thailand, and his second doctoral degree in Ancient Indian and Asian studies from Magadh University, India. He specializes in outsourcing management, organization development, and SME management. His contact e-mail is: thongphon.p@psu.ac.th,deaw_t@hotmail.com.

\section{REFERENCES}

1. Bedian, A. G., \& Hunt, J. G. 2006. Academic amnesia and vestigial assumptions of our forefathers. Leadership Quarterly, 17, 190-205.

2. Crossan, M., Vera, D. \& Nanjad, L. 2008. Transcendent leadership: Strategic leadership in dynamic environments. Leadership Quarterly, 19, 569-581.

3. Elenkov, D. S., \& Manev, I. M. 2005. Top management leadership and influence on innovation: The role of sociocultural context. Journal of Management, 31, 381-402.

4. Hongtongkam, P. 1997. Problem and Guideline for Thai Municipality. Bangkok: Chao Praya Print.

5. Peter M.Senge. 1990. The Fifth Discipline: The Art and Practice of the Learning Organization. Doubleday, $1^{\text {st }}$ edition, New York: Currency Doubleday.

6. $\quad$ Prasertsri, R. 2001. Leadership. Bangkok: Tanatach Printing.

7. Set Khajon, S. 2003. A Role of Administrator to Organization Success. SWU educational administration journal, 2(4), 27-30.

8. The Department of Local Administration. 2006. Sevice mind of Local Administrative Organization. Bangkok: Department of Local Administration.

9. Valaisathien, P. and et al. 2000. The Process and Development Technique. Bangkok: Thammasart University Press. 